\title{
Sinergitas Marketing dan Promotional Mix dalam Konsep Sustainable Tourism sebagai Strategi Komunikasi Pemasaran
}

\author{
Nabila Diandra Putri', Kartika Ayu Ardhanariswari ${ }^{2}$ \\ 1,2Jurusan Ilmu Komunikasi, Fakultas Ilmu Sosial dan Ilmu Politik, \\ Universitas Pembangunan Nasional "Veteran" Yogyakarta \\ Jl. Babarsari No. 2 TambakbayanYogyakarta, 55281, Indonesia \\ Email: nabiladiandra28@gmail.com ${ }^{1}$; ardhanariswari_ayu@yahoo.com ${ }^{2 *}$ \\ *Corresponding author
}

\begin{abstract}
Along with the increasing number of tourists and tourist destinations, the Government through the Tourism Office of Sleman Regency seeks to improve the facilities and regulations that support tourism activities. The purpose of this research is to analyze the marketing communication strategies carried out by Pulewulung tourism village managers in implementing the concept of sustainable tourism communication and to know the supporting factors and inhibition of the marketing communication strategy. The research method used is qualitative descriptive research. Data collection techniques are carried out with interviews and documentation. The results of the research were obtained that Pulewulung Tourism Village in its marketing strategy uses the concept of the marketing mix in 4P namely Product, Price, Place, and Promotion. Promotional activities are supported by a promotion mix, but managers only use three of the five promotional strategies, namely direct marketing, public relations and publicity, and advertising. Pulewulung Tourism Village in marketing strategy implements several tourism communication activities and marketing activities are carried out by managers who are still teenagers. The management of Pulewulung Tourism Village is also in collaboration with several parties that help the implementation of sustainable tourism so that the establishment of this tourist village can provide many benefits for the surrounding residents. This research contributes in the form of new policy recommendations marketing strategy Marketing Mix and Promotional Mix on tourism activities in Pulewulung Tourism Village can be sustainable that can be applied in other tourism areas.
\end{abstract}

Keywords: Marketing Communication; Pulewulung Tourism Village; Sustainable Tourism

\begin{abstract}
Abstrak
Seiring meningkatnya jumlah wisatawan dan destinasi wisata, Pemerintah melalui Dinas Pariwisata Kabupaten Sleman berupaya meningkatkan sarana dan prasaran yang menunjang kegiatan pariwisata. Tujuan dari penelitian ini untuk menganalisis strategi komunikasi pemasaran yang dilakukan pengelola Desa Wisata Pulewelung dalam menerapkan konsep komunikasi pariwisata berkelanjutan (sustainable tourism) serta mengetahui faktor pendukung dan penghambat strategi komunikasi pemasaran tersebut. Metode penelitian yang digunakan adalah penelitian deskriptif kualitatif. Teknik pengumpulan data dilakukan dengan wawancara dan dokumentasi. Hasil penelitian diperoleh bahwa Desa Wisata Pulewulung dalam strategi pemasarannya menggunakan konsep marketing mix dalam 4P yaitu Product, Price, Place, dan Promotion. Kegiatan promosi didukung dengan promotion mix atau bauran promosi, namun pengelola hanya menggunakan tiga dari lima strategi promosi yaitu direct marketing, public relations dan publisitas, serta periklanan. Desa Wisata Pulewulung dalam strategi pemasaran menerapkan beberapa kegiatan komunikasi pariwisata dan kegiatan pemasarannya dilakukan oleh pengelola yang masih berusia remaja. Pengelolaan Desa Wisata Pulewulung ini juga bekerjasama dengan beberapa pihak yang membantu penerapan pariwisata berkelanjutan (sustainable tourism) sehingga berdirinya desa wisata ini dapat memberi banyak kemanfaatan bagi warga sekitar. Penelitian ini memberikan kontribusi berupa rekomendasi kebijakan baru strategi komunikasi pemasaran Marketing Mix dan Promotional Mix pada kegiatan pariwisata di Desa Wisata Pulewulung dapat berkelanjutan yang dapat diterapkan di daerah pariwisata lainnya.
\end{abstract}

Kata kunci: Komunikasi Pemasaran; Desa Wisata Pulewulung; Pariwisata Berkelanjutan (Sustainable Tourism)

\section{Pendahuluan}

Daerah Istimewa Yogyakarta merupakan sebuah provinsi di Jawa Tengah yang dikenal dengan slogan Kota Pelajar, Kota Perjuangan, serta sebagai pusat kebudayaan dan pariwisata
(Haryono, 2009). Hal ini dikarenakan banyak sekali tujuan wisata yang mempesona dan terkenal di Indonesia bahkan hingga ke luar negeri, terlebih karena provinsi ini dibagi dalam lima kabupaten atau kota. Jumlah 
wisatawan yang berkunjung ke Daerah Istimewa Yogyakarta semakin bertambah dari tahun ke tahun (Suparwoko \& Dewi, 2015). Saat ini setiap kabupaten atau kota mengembangkan potensi destinasi wisata. Tahun 2017 Kabupaten Sleman menempati posisi dua teratas dari lima kabupaten atau kota di Daerah Istimewa Yogyakarta dengan mendapatkan kunjungan wisatawan secara domestik maupun mancanegara sejumlah 6.814 .558 orang. Jumlah tersebut meningkat dari tahun 2016 yang berjumlah 5.685.301 orang sehingga terjadi peningkatan jumlah wisatawan sebanyak 1.129.257 orang.

Pemerintah Kabupaten Sleman berupaya meningkatkan sarana prasarana pariwisata yang menunjang dengan menyediakan akomodasi, transportasi, kuliner, dan tentunya penginapan yang dapat dimanfaatkan wisatawan saat berkunjung. Hal ini sesuai dengan penelitian yang dilakukan oleh Sabon, Perdana, Koropit, dan Pierre (2018) mengenai strategi peningkatan sektor pariwisata. Penelitian tersebut menyatakan bahwa perlu perhatian khusus pada pembangunan infrastruktur, kebijakan pariwisata, strategi pemasaran, dan pendanaan agar meningkatkan jumlah pendatang. Penelitian lain mengenai strategi pemasaran dilakukan oleh Maharani, Lestari, dan Suparno (2009). Penelitian tersebut menunjukkan bahwa strategi komunikasi yang digunakan dengan memanfaatkan bauran promosi (advertising, personal selling, dan sales promotion) mampu meraih konsumen sesuai target perusahaan dan dapat meningkatkan konsumen. Pada penelitian ini meningkatkan konsumen adalah meningkatkan upaya pariwisata.

Peningkatan upaya pariwisata yang juga dilakukan Pemerintah Kabupaten Sleman yaitu bekerjasama dengan Pemerintah Daerah Istimewa Yogyakarta. Kerjasama perihal perhotelan, terlebih dengan adanya moratorium pendirian hotel, apartemen, dan kondotel di Kabupaten Sleman hingga tahun 2021 mendatang. Awal tahun 2019 Pemerintah Kota Yogyakarta membuat kebijakan baru dengan membuka kesempatan bagi investor yang ingin mendirikan hotel bintang empat atau bintang lima serta kepada masyarakat yang ingin mendirikan homestay ataupun guesthouse (Jogjatravel.com, 2019). Upaya untuk mendorong pariwisata lokal agar semakin maju ini melalui pengadaan desa wisata, terlebih saat ini Pemerintah Kabupaten Sleman melalui Dinas Pariwisata Kabupaten Sleman sedang gencar-gencarnya meningkatkan kualitas pelayanan dan jumlah desa wisata. Hingga tahun 2018 terdapat 36 desa wisata di Kabupaten Sleman terdiri dari desa wisata tumbuh, berkembang, dan mandiri (Dinas Pariwista Kabupaten Sleman, 2018).

Tidak hanya sebagai tujuan wisata, berkembangnya desa wisata juga berdampak baik bagi peningkatan ekonomi masyarakat di sekitarnya. Pasalnya desa wisata memiliki potensi yang cukup besar terlebih jika pengelolaannya dilakukan oleh warga setempat. Perkembangan desa wisata tidak terlepas dari peran pemerintah dalam menetapkan suatu pedoman dalam kegiatan komunikasi pemasaran pariwisata dengan model analisis strategi komunikasi pemasaran pariwisata yang digunakan dalam melakukan pemasaran kepada wisatawan mancanegara. Hal ini terlihat dalam strategi dan program pemasaran pariwisata DIY, model analisis yang digunakan pemerintah adalah dengan formula BAS (Branding, Advertising, dan Selling). Hasil yang ingin diwujudkan dalam model analisis pemerintah adalah selling yang diukur dengan banyaknya wisatawan yang berkunjung dan prestasi atau awards yang didapat. Pelaksanaan kegiatan pariwisata sehari-hari, pengelola desa wisata juga memiliki strategi yang diterapkan secara khusus dan bertujuan untuk mempertahankan keberadaan desa wisatanya. Strategi ini diterapkan oleh pengelola dengan beberapa kegiatan promosi yang bertujuan untuk meningkatkan branding. Branding dinilai dapat meningkatkan kepercayaan seseorang agar memercayai suatu hal (Hermawan, 2019), khususnya pada penelitian ini adalah strategi pariwisata. 
Strategi tersebut memeroleh hasil yang berbeda antara hasil strategi komunikasi pemasaran pariwisata pemerintah dengan hasil strategi komunikasi pemasaran yang diterapkan pengelola desa wisata. Perbedaan hasil strategi tersebut harus berjalan secara beriringan, sehingga dapat membantu segala hal mengenai pengelolaan desa wisata dan memperjelas peran pemerintah dalam memperkenalkan berbagai destinasi wisata yang dimiliki. Pengelolaan desa wisata juga harus mampu memanfaatkan sumber daya alam dan sumber daya manusia yang ada di sekitar sehingga menunjukkan bahwa hal tersebut sejalan dengan konsep pariwisata berkelanjutan (Sustainable Tourism) sebagai program Kementerian Pariwisata. Bersamaan dengan penerapan konsep tersebut, di tahun 2018 Kementerian Pariwisata giat mengembangkan pembangunan destinasi pariwisata berkelanjutan dengan penghargaan ISTA (Indonesia Sustainable Tourism Award).

Tahun 2018 terpilih tiga destinasi pariwisata berkelanjutan di Kabupaten Sleman yang masuk dalam nominasi ISTA, yaitu Museum Gunung Merapi, Desa Wisata Pancoh, dan Desa Wisata Pulewulung. Destinasi wisata yang paling menarik perhatian peneliti adalah Desa Wisata Pulewulung yang terletak di Bangunkerto, Turi, Sleman. Desa Wisata Pulewulung belum genap berusia dua tahun karena baru berdiri pada 14 Januari 2017 dan pengelolanya terdiri dari beragam usia, tidak hanya yang berusia dewasa namun ada juga yang berusia remaja. Berdasarkan hasil observasi pra-penelitian, kegiatan promosi Desa Wisata Pulewulung yang saat ini sudah dilakukan hanya sebatas media sosial seperti Facebook, Instagram dan Blogspot. Temuan dari penelitian dari firma riset Pew Research yang menyatakan bahwa jejaring sosial Facebook perlahan ditinggalkan oleh penggunanya. Hal tersebut sesuai dengan penelitian yang dilakukan Adhanisa dan Fatchiya
(2017) yang menyatakan bahwa penggunaan Instagram dan website menarik perhatian dan keingintahuan khalayak, namun untuk menarik keinginan dan tindakan masih kurang, sehingga diperlukan komunikasi pemasaran yang baik.

\section{Teori Komunikasi Pemasaran Terpadu}

Landasan Desa Wisata Pulewulung memiliki potensi dalam melakukan komunikasi pemasaran adalah jasa pariwisata. Pengelola desa wisata bekerjasama dengan Dinas Pariwisata Kabupaten Sleman dalam pemberdayaan sumber daya alam dan sumber daya manusia. Peneliti menerapkan teori komunikasi pemasaran terpadu dalam menerapkan konsep pariwisata berkelanjutan mengingat destinasi pariwisata seperti ini menjadi tujuan utama bagi wisatawan dalam maupun luar negeri. Komunikasi pemasaran terpadu adalah mengkoordinasikan dan mengintegrasikan saluran komunikasi organisasi untuk menyampaikan pesan secara lugas, jelas, konsisten, dan dapat menarik perhatian konsumen mengenai organisasi tersebut (Kartikasari, 2014). Saluran komunikasi saat ini dapat memanfaatkan kemajuan teknologi komunikasi dan informasi saat ini yang menuntut pelaku pariwisata untuk semakin berpengalaman dalam mempromosikan serta memasarkan produknya kepada masyarakat luas. Pemasaran produk dengan memanfaatkan komunikasi pemasaran sangat penting, karena lebih memfokuskan ke penerima serta makna yang diterima (Kriyantono, 2019). Penelitian ini dapat menjadikan Desa Wisata Pulewulung sebagai acuan bagi desa wisata lain di Kabupaten Sleman maupun di daerah lain, serta mengetahui strategi komunikasi pemasaran pariwisata yang dilakukan oleh pengelola agar Desa Wisata Pulewulung mampu bertahan dan bersaing dengan 35 desa wisata lainnya di Kabupaten Sleman. Strategi komunikasi pemasaran pariwisata yang baik, tentu berkaitan dengan perencanaan komunikasi yang baik. 


\section{Teori Perencanaan Komunikasi}

Penelitian ini menggunakan teori perencanaan komunikasi menurut Charles Berger (Littlejohn, 2017: 184-185). Teori perencanaan komunikasi digunakan untuk menjelaskan proses komunikasi yang dilalui dalam merencanakan komunikasi (Aulia \& Irma, 2017). Pada penelitian ini teori perencanaan komunikasi digunakan untuk mengetahui strategi komunikasi pemasaran Desa Wisata Pulewulung dalam menerapkan konsep komunikasi pariwisata berkelanjutan. Suatu organisasi atau perusahaan untuk mencapai tujuan harus memiliki langkahlangkah perencanaan sehingga mengarah pada pembentukan strategi dan memiliki dampak yang baik bagi desa (Lestari \& Dewi, 2010), terlebih dalam mempromosikan suatu destinasi wisata.

\section{Metode Penelitian}

Jenis penelitian yang digunakan adalah penelitian kualitatif dengan pendekatan deskriptif karena dilakukan untuk menjelaskan data-data berupa kata, gambar, dan bukan berupa angka. Peneliti menggunakan jenis penelitian kualitatif karena dapat menggambarkan dan menjelaskan keadaan yang sebenarnya atau realita sosial yang dilakukan peneliti dalam meneliti strategi komunikasi pemasaran Desa Wisata Pulewulung dalam menerapkan konsep pariwisata berkelanjutan (Sustainable Tourism).

Jenis data yang digunakan dalam penelitian ini meliputi data primer dan data sekunder. Data primer diperoleh langsung dari narasumber, melalui wawancara mendalam di Desa Wisata Pulewulung dan di Kantor Dinas Pariwisata Kabupaten Sleman yang dilakukan sejak bulan Desember 2018. Data sekunder dalam penelitian ini adalah data dari internet seperti website pariwisata.slemankab.go.id, Facebook, Instagram, dan Blog Desa Wisata Pulewulung. Peneliti juga mendapatkan data organisasi berupa Buku Profil Desa Wisata Pulewulung Edisi ketiga yang berisi tentang dokumentasi gambar, berita, dan bukti alat promosi, serta literatur buku-buku yang berkaitan dengan penelitian.
Teknik pengumpulan data dalam penelitian ini adalah wawancara dan dokumentasi. Wawancara adalah pertemuan dua orang untuk bertukar informasi dan ide melalui tanya jawab, sehingga dapat dikonstruksikan makna dalam suatu topik tertentu (Sugiyono, 2013: 317). Wawancara dilakukan kepada subjek penelitian yaitu Ketua Pengelola Desa Wisata Pulewulung, Koordinator PMC (Pulewulung Media Center), Kepala Divisi Pengembangan Usaha Pariwisata Dinas Pariwisata Kabupaten Sleman, warga serta pengunjung di Desa Wisata Pulewulung.

Teknik analisis data yang digunakan dalam penelitian ini mencakup tiga komponen dalam penelitian kualitatif yakni reduksi data, sajian data, dan penarikan simpulan serta verifikasi. Uji keabsahan data dilakukan dengan pengujian kredibilitas atau Credibility melalui uji triangulasi dengan sumber data. Uji triangulasi sumber data membandingkan dan memeriksa informasi yang didapat dari hasil wawancara dan menganalisa dokumen yang ada. Peneliti melakukan wawancara dengan seluruh narasumberkemudian peneliti menggabungkan seluruh hasil penelitian yang diperoleh dari wawancara dan dokumentasi untuk menguji keabsahan hasil penelitian dengan peneliti, metode, teori dan sumber data.

\section{Hasil Penelitian dan Pembahasan}

Hasil penelitian diperoleh bahwa kegiatan strategi komunikasi pemasaran Desa Wisata Pulewulung merupakan salah satu bentuk upaya dalam bidang promosi yang memiliki pengaruh sangat besar dalam menentukan kunjungan wisatawan. Desa Wisata Pulewulung sebagai salah satu destinasi pariwisata yang tergolong masih baru harus memperluas strategi komunikasi pemasaran pariwisatanya supaya masyarakat lebih tahu dan mengenal Desa Wisata Pulewulung. Manfaat desa wisata ini dikenal oleh masyarakat, maka dengan sendirinya masyarakat datang ke Desa Wisata Pulewulung untuk melakukan berbagai kegiatan sesuai dengan yang pengelola tawarkan. Perwujudan 
tujuan tersebut maka pengelola Desa Wisata Pulewulung harus membuat strategi secara cepat dan tepat dalam hal komunikasi pemasaran pariwisata, mengingat bahwa persaingan di industri pariwisata saat ini semakin kencang.

Sesuai dengan Teori Perencanaan Komunikasi oleh Charles Berger, perencanaan strategi komunikasi pemasaran pariwisata yang dilakukan oleh pengelola sifatnya masih cenderung secara internal. Pengelola masih memperbaiki apa yang ada di dalam manajemen Desa Wisata Pulewulung. Kegiatan manajemen komunikasi pariwisata sudah diterapkan sejak awal desa wisata ini berdiri oleh ketua pengelola. Ketua pengelola berinisiatif membangun Desa Pulewulung menjadi sebuah desa wisata yang memberi kemanfaatan bagi masyarakat serta lingkungan sekitar. Penerapan sapta pesona kepada masing-masing individu di kawasan Desa Wisata Pulewulung dirasa sangat penting oleh pengelola serta harus ditanamkan sejak dini sehingga senantiasa menjadi acuan dalam melaksanakan kegiatan komunikasi pariwisata di Pulewulung. Kegiatan manajemen komunikasi pariwisata pun dirasa sudah berjalan. Ketua pengelola memiliki jiwa kepemimpinan atau leadership yang tinggi serta ulet dalam membangun Desa Wisata Pulewulung sehingga mampu mengatur dan mengoordinasikan anggota pengelola dalam melakukan perencanaan komunikasi pemasaran pariwisata.

Perencanakan kegiatan promosi, pengelola Desa Wisata Pulewulung mengimplementasikan kegiatan komunikasi kelompok pariwisata dalam kegiatan-kegiatan yang dilaksanakan di PMC (Pulewulung Media Center). PMC sudah berdiri lebih dahulu daripada Desa Wisata Pulewulung, namun jika pengelolaan dan pengoordinasian PMC (Pulewulung Media Center) dilakukan secara maksimal, maka kegiatan komunikasi pemasaran pariwisata ke depannya dirasa akan maksimal. Terlebih karena PMC (Pulewulung Media Center) dilengkapi dengan wifi hotspot, komputer, tempat penyimpanan data, serta peralatan untuk dokumentasi seperti kamera dan tripod, akan lebih mendukung kegiatan komunikasi pemasaran pariwisata.

Segi segmentasi, pengelola Desa Wisata Pulewulung sendiri yang melakukan pemetaan pada target pengunjung yang disasar. Terlebih karena Desa Wisata Pulewulung sebagai destinasi pariwisata yang masih tergolong baru, maka harus lebih cepat dan tepat menentukan target sasaran sehingga pengunjung yang datang tidak hanya berasal dari dalam negeri tetapi juga dari luar negeri atau mancanegara. Pada proses segmentasi, pengelola Desa Wisata Pulewulung belum menetapkan karakteristik khusus dari calon pengunjung yang disasar, seperti lebih berfokus pada wisatawan dari dalam negeri atau wisatawan dari luar negeri atau mancanegara. Pembagian segmentasi yang ini ditentukan oleh pengelola Desa Wisata Pulewulung pada dasarnya terbagi menjadi tiga yaitu segmentasi demografis, geografis, dan psikografis. Ketiga penggolongan segmentasi ini dilakukan oleh pengelola melalui bantuan media sosial Facebook sebagai implementasi kegiatan komunikasi online pariwisata.

Setiap bulan pengelola Desa Wisata Pulewulung selalu mengadakan rapat rutin terkait evaluasi kegiatan yang direncakan dan ditetapkan. Kegiatan evaluasi seperti ini dirasa sangat penting mengingat dalam teori perencanaan komunikasi oleh Charles Berger ini menjelaskan bahwa suatu proses perencanaan yang dilakukan organisasi atau perusahaan harus melalui tahap evaluasi terhadap program sebelumnya yang sudah pernah dilaksanakan. Evaluasi ini berupa rapat rutin yang membahas tentang strategi komunikasi pemasaran pariwisata meliputi progres desa wisata, jumlah pengunjung dan jumlah pemasukan (keuangan Desa Wisata Pulewulung), perencanaan kegiatan promosi, serta beberapa perbaikan yang harus dilakukan oleh pengelola Desa Wisata Pulewulung. 
Implementasi strategi komunikasi pemasaran pariwisata, terdapat dua kajian yang berbeda, yaitu secara teoritis maupun secara praktis. Hal ini terjadi karena dalam pelaksanaan strategi komunikasi pemasaran pariwisata dilakukan oleh dua pihak, yaitu dari pengelola Desa Wisata Pulewulung dan dari pemerintah yang memberikan kebijakan mengenai strategi komunikasi pemasaran pariwisata melalui pemerintah daerah. Secara teoritis, strategi komunikasi pemasaran pariwisata di Desa Wisata Pulewulung berjalan sesuai dengan konsep komunikasi pemasaran terpadu. Strategi komunikasi pemasaran terpadu ini diterapkan oleh pengelola Desa Wisata Pulewulung dengan menggunakan 4 unsur dalam bauran pemasaran (marketing mix) atau yang lebih dikenal dengan istilah 4P.

Unsur Product ditonjolkan dengan keunggulan produk hasil olahan salak seperti sirup salak, dodol salak, jenang salak hingga brownies salak yang dikelola melaui UKM dan dijalankan oleh para ibu. Hasil olahan inilah yang dapat dijadikan sebagai oleh-oleh khas Pulewulung. Pengelola juga menonjolkan berbagai paket wisata yang dapat dilakukan di Desa Wisata Pulewulung seperti kegiatan outbond, trekking sungai, bermain di wahana air, budidaya salak, petik salak, mengikuti kegiatan membatik, mempelajari kerajianan janur manten, hingga membuat gelang dari benang. Namun kegiatan yang belum ditonjolkan oleh pengelola Desa Wisata Pulewulung adalah kegiatan yang meliputi aspek sosial dan budaya sehingga implementasi komunikasi visual pariwisata yang menonjolkan ikol local tourism belum terlaksana, hanya sebatas UKM dengan komunikasi kewirausahaan atau enterpreneruship.

Unsur Price yang ditawarkan oleh Desa Wisata Pulewulung sangat terjangkau karena pengelola sadaran bahwa keberadaan Desa Wisata Pulewulung ini masih sangat baru sehingga tidak bisa mengeluarkan tarif yang tinggi. Unsur Place yang ditetapkan oleh pengelola Desa Wisata
Pulewulung diwujudkan dengan lokasi Desa Wisata Pulewulung tidak terlalu jauh dari pusat Kota Yogyakarta. Aksesnya mudah dan dapat dideteksi dengan aplikasi Google Maps. Lokasi dinyatakan aman karena bukan terletak pada KRB (Kawasan Rawan Bencana). Terdapat sejumlah tempat parkir atau tempat transit kendaraan pengunjung. Namun ukurannya masih kurang besar untuk kendaraan seperti bus dan travel.

Unsur Promotion yang dilakukan oleh pengelola Desa Wisata Pulewulung menerapkan konsep bauran promosi (promotion mix) oleh Kotler dan Armstrong (2008) (Resmawa, 2017). Pengelola Desa Wisata Pulewulung hanya menerapkan tiga cara di antaranya Direct Marketing, Public Relations dan periklanan. Hal pertama yang dilakukan oleh pengelola Desa Wisata Pulewulung dalam implementasi kegiatan komunikasi pemasaran pariwisata adalah melalui pemasaran langsung atau direct marketing melalui media sosial Facebook, Instagram, serta Blog. Penggunaan media sosial sebagai media promosi desa wisata belum sepenuhnya maksimal. Pesan yang disampaikan tidak semuanya update to date atau selalu diperbarui setiap saat.

Kegiatan kehumasan ini baru diwujudkan dalam kerjasama dengan Dinas Pariwisata Kabupaten Sleman serta Hotel Grand Tjokro. Salah satu implementasi kerjasama dengan Dinas Pariwisata Kabupaten Sleman adalah dengan Pelatihan STD (Sustainable Tourism Development) dengan pemanfaatan sampah limbah barang bekas. Bentuk kerjasama antara Desa Wisata Pulewulung dengan Hotel Grand Tjokro berupa program One Hotel One Village atau satu hotel mendampingi satu desa wisata yang diperkenalkan oleh Dinas Pariwisata Kabupaten Sleman. Jika tamu Hotel Grand Tjokro ingin melakukan kegiatan wisata seperti petik salak dan mengikuti outbond, maka pihak hotel mengirimkan para tamu ke Desa Wisata Pulewulung. 
Kegiatan periklanan atau advertising menggunakan media Leaflet yang terdiri dari deskripsi singkat mengenai potensi desa wisata, letak serta paket wisata yang ditawarkan. Selain itu juga dilengkapi dengan beberapa dokumentasi kegiatan yang bertujuan membuat calon pengunjung semakin tertarik untuk berwisata ke Pulewulung. Penyebarluasannya belum efektif karena hanya diberikan kepada pengunjung yang meminta, selebihnya hanya dibawa oleh anggota pengelolake sekolah, kampus atau tempatbekerja.

Secara praktis, strategi komunikasi pemasaran pariwisata diterapkan dengan model analisis dari pemerintah dalam formula BAS (Branding, Advertising, dan Selling). Pada Branding, pemerintah daerah melalui Dinas Pariwisata Kabupaten Sleman sudah berupaya menerapkannya kepada Desa Wisata Pulewulung. Dinas Pariwisata Kabupaten Sleman mempromosikan Desa Wisata Pulewulung dengan adanya artikel mengenai desa wisata yang ada di Kabupaten Sleman, salah satunya yaitu Desa Wisata Pulewulung. Dinas Pariwisata Kabupaten Sleman juga mencetak booklet desa wisata yang ada di Kabupaten Sleman beserta penjelasan singkat mengenai potensi yang bisa didapat di sejumlah desa wisata tersebut. Festival yang pernah diadakan oleh Dinas dan diikuti oleh Desa Wisata Pulewulung hanya berupa festival desa wisata yang ada di Kabupaten Sleman.

Advertising yaitu dengan pemasangan iklan di media cetak seperti koran atau majalah serta di event-event mancanegara puun belum terlaksana. Hal ini dikarenakan berdirinya Desa Wisata Pulewulung masih tergolong baru sehingga kegiatan pemasaran pariwisata oleh Dinas belum sepenuhnya terlaksana. Kerjasama dengan pelaku industri pariwisata hanya terjadi dengan hotel yang ada di Yogyakarta, belum menjalin kerjasama dengan hotel di luar Yogyakarta bahkan di mancanegara. Kerjasama dengan maskapai penerbangan serta agen tour and travel secara lokal maupun mancanegara juga belom terlaksana.
Selling, Dinas Pariwisata Kabupaten Sleman memfasilitasi penjualan paket wisata yang ditawarkan oleh Desa Wisata Pulewulung melalui trade shows berupa Pameran Potensi Daerah Sleman 2018. Kegiatan ini bertujuan untuk mengenalkan berbagai potensi, budaya, dan produk unggulan daerah Sleman. Dengan adanya kegiatan Pameran Potensi Daerah Sleman ini diharapkan citra Kabupaten Sleman dapat semakin baik sebagai daerah yang berprospek untuk investasi dalam rangka menghadapi pasar global dan Masyarakat Ekonomi ASEAN (MEA).

Adanya desa wisata dan dikelola secara bersama-sama oleh pengelola yang merupakan warga di Desa Pulewulung, membuat desa wisata ini semakin maju dan berkembang. Pemasukan dari pengunjung yang datang untuk melakukan kegiatan wisata dan membeli segala produk olahan dari Desa Wisata Pulewulung dimanfaatkan pengelola untuk memperbaiki serta menambah fasilitas yang ada. Dari aspek lingkungan, pengelola menerapkan sapta pesona dalam kesehariannya dengan menjaga kerapian dan kebersihan lingkungan. Pengelola aktif berpartisipasi dalam kegiatan yang diadakan oleh Dinas seperti pelatihan pengolahan limbah.

Pada proses kegiatan komunikasi pemasaran pariwisata ditemukan beberapa faktor pendukung dan faktor penghambat. Faktor pendukung dari strategi komunikasi pemasaran oleh pengelola Desa Wisata Pulewulung adalah sumber daya manusia atau pengelola yang jumlahnya tidak terlalu banyak namun memiliki semangat untuk berkembang yang sangat tinggi. Semangat untuk berkembang bersama ini diwujudkan dengan saling membantu atau gotong royong. Kerjasama yang dilakukan oleh Desa Wisata Pulewulung juga tidak hanya terjadi pada instansi pemerintahan tetapi juga dengan pihak swasta yang sama-sama berkiprah di industri pariwisata. Faktor penghambat di antaranya adalah alih fungsi lahan dari yang semula merupakan lahan milik desa kini berubah fungsinya menjadi lahan untuk industri pariwisata memakan 
waktu cukup lama, kegiatan komunikasi pemasaran pariwisata yang difokuskan hanya dari media sosial, serta persaingan di industri pariwisata semakin membuat pengelola Desa Wisata Pulewulung harus memutar otak untuk melaksanakan upaya pemasaran. Terlebih karena desa wisata ini terletak di kawasan Agro Wisata Turi dan letak desa wisata satu dengan yang lainnya berdekatan, maka pengelola lebih keras lagi menggali potensi dan mengembangkannya supaya bisa menjadi daya tarik wisata.

Strategi komunikasi pemasaran yang digunakanDesaWisataPulewulungmenggunakan konsep 4P (Gambar 1), yaitu product, price, place, dan promotion, serta direct marketing, public relations, dan publisitasi periklanan. Hal ini dilihat kelebihan penggunaan strategi ini yang sejalan dengan penelitian yang dilakukan oleh Aprilya (2017) yang menyatakan bahwa peluang pelanggan besar karena memberikan

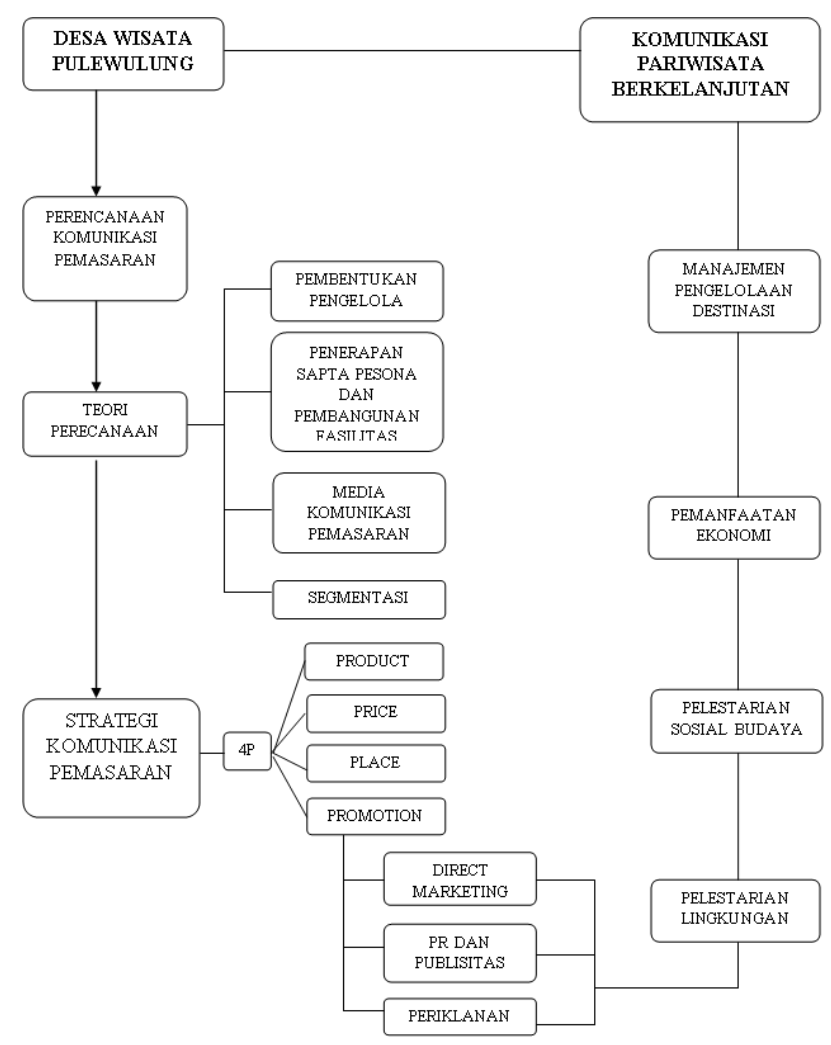

Gambar 1 Strategi Komunikasi Pemasaran Desa Wisata Pulewulung

Sumber: Hasil olahan peneliti (2019) produk berdasar kebutuhan pasar, harga dan kualitas yang diterima, penggunaan Instagram sebagai tempat berbisnis, dan berbagai promosi yang baik. Sinergitas strategi komunikasi pemasaran 4P Marketing Mix dan Promotional Mix ini dapat diterapkan diberagai tempat untuk meningkatkan nilai ekonomi. Keberhasilan strategi yang telah disusun membawa keuntungan bagi organisasi untuk meningkatkan pendapatan dan kepercayaan masyarakat sebagai wisatawan.

\section{Simpulan}

Strategi komunikasi pemasaran yang dilaksanakan oleh Desa Wisata Pulewulung masih sama dengan kegiatan pemasaran pada umumnya sehingga belum memiliki strategi khusus dalam pengelolaannya dan lebih berfokus pada kegiatan bauran promosi melalui media sosial seperti Instagram, Facebook, dan Blog. Pelaksanaan strategi komunikasi pemasaran yang dilakukan pengelola Desa Wisata Pulewulung juga belum efektif karena masih sebatas pemasaran di daerah setempat dan alat yang digunakan juga masih terbatas. Penerapan komunikasi pariwista dalam strategi komunikasi pemasaran yang dilakukan oleh pengelola belum semua berjalan. Masih ada beberapa aspek yang perlu dikaji lebih jauh sehingga dalam menjalin kerjasama dengan berbagai pihak akan lebih efektif dan semakin memperkenalkan Desa Wisata Pulewulung sebagai salah satu destinasi pariwisata yang ada di Kabupaten Sleman kepada masyarakat luas.

Faktor pendukung strategi komunikasi pemasaran Desa Wisata Pulewulung adalah sumber daya manusia di desa wisata tersebut walaupun jumlahnya sedikit namun memiliki semangat untuk berlatih dan berkembang yang tinggi dan melakukan kerjasama dengan pihakpihak yang berkompeten di bidang pariwisata. Faktor penghambat strategi komunikasi pemasaran Desa Wisata Pulewulung adalah perubahan fungsi lahan desa menjadi lahan untuk industri pariwisata memerlukan perizinan yang cukup memakan waktu lama, kegiatan 
promosi yang hanya difokuskan pada media sosial padahal pengelola memiliki potensi untuk melakukan promosi dengan berbagai macam media, serta persaingan di industri pariwisata yang membuat pengelola harus lebih kerja keras dalam menggali potensi desa wisata agar dapat dijadikan daya tarik wisata.

Penerapan konsep pariwisataberkelanjutan di Desa Wisata Pulewulung didukung oleh berbagai kegiatan yang diadakan oleh Dinas Pariwisata Kabupaten Sleman sehingga kualitas dan kemampuan masing-masing individu pengelola bisa meningkat dan dapat menjalankan kegiatan pariwisata di Pulewulung dalam menggerakkan seluruh aspek kehidupan yang ada, sesuai dengan aspek utama pembangunan pariwisata berkelanjutan yaitu manajemen pengelolaan destinasi, pemanfaatan ekonomi, pelestarian sosial budaya, dan pelestarian lingkungan.

Berdasarkan hasil dari penelitian yang telah dilakukan oleh peneliti, maka saran yang dapat disampaikan yaitu: a) Pengelola Desa Wisata Pulewulung harus lebih inovatif dengan lebih memanfaatkan berbagai alat atau media dalam kegiatan komunikasi pemasaran pariwisata dalam mengembangkan dan memperluas kegiatan promosi serta pemasaran agar Desa Wisata Pulewulung dapat semakin terkenal oleh masyarakat luas; b) Pengelola Desa Wisata Pulewulung harus segera memperluas kerjasama dengan berbagai pihak dalam bidang pariwisata seperti agen tour travel, maskapai penerbangan, serta dengan hotel-hotel yang tidak hanya berada kawasan Kabupaten Sleman maupun Kota Yogyakarta; c) Pengelola Desa Wisata Pulewulung harus lebih menerapkan segala kajian dalam komunikasi pariwisata seperti manajemen destinasi pariwisata, komunikasi visual pariwisata, komunikasi online pariwisata, komunikasi transportasi pariwisata, komunikasi kelompok pariwisata, serta publicrelations karena kegiatan komunikasi pariwisata tersebut dapat membantu penyebaran pesan-pesan komunikatif dari pengelola usaha pariwisata kepada pengunjung dan calon pengunjung. Penelitian ini memberikan kontribusi berupa rekomendasi kebijakan baru untuk menerapkan strategi komunikasi 4P Marketing Mix dan Promotional Mix di daerah lain yang ingin meningkatkan daya tarik pengunjung secara berkelanjutan.

\section{Daftar Pustaka}

Adhanisa, C., \& Fatchiya, A. (2017). Efektivitas Website dan Instagram Sebagai Sarana Promosi Kawasan Wisata Berbasis Masyarakat. Jurnal Sains Komunikasi dan Pengembangan Masyarakat [JSKPM], 1(4), 451-466. https:// doi.org/10.29244/jskpm.1.4.451-466 Aprilya, T. (2017). Strategi Komunikasi Pemasaran Nadyasfashop melalui Instagram dalam Meningkatkan Kepercayaan Customerdi Samarinda. eJournal Ilmu Komunikasi, 5(1), 13-23. Aulia, R., \& Irma, A. (2017). Strategi Komunikasi Interpersonal Orang Tua dan Anak Dalam Meningkatkan Rasa Percaya Diri Anak Penyandang Disabilitas. Jurnal Ilmiah Mahasiswa FISIP Unsyiah, 2(1), 16-29. Diakses dari http://www.jim. unsyiah.ac.id/FISIP/article/view/2313 Dinas Pariwisata Kabupaten Sleman. (2018). Laporan Hasil Kajian Penerapan Pembangunan Pariwisata Berkelanjutan Bagi Desa Wisata di Kabupaten Sleman. Sleman: Dinas PariwisataKabupaten Sleman. Dinas Pariwisata Daerah Istimewa Yogyakarta. (2017). Strategi dan Program Pemasaran Pariwisata DIY. Yogyakarta: Jogja Istimewa. Haryono, S. (2009). Analisis Brand Image Yogyakarta Sebagai Kota Pelajar. Jurnal Ilmu Komunikasi, 7(3), 301-309. Diakses d a r i h t t p : //jurnal.upnyk.ac.id/ index.php/komunikasi/article/view/28 Hermawan, E. (2019). Strategi Kementerian Pariwisata Indonesia dalam Meningkatkan Branding Wisata Halal. Referensi: Jurnal Ilmu Manajemen dan Akutansi, 7(2), 8795. http://dx.doi.org/10.33366/ref.v7i2.1512 
Jogjatravel.com. (2019). Pemkot Yogyakarta Cabut Moratorium Pendirian Hotel. Jogjatravel.comdiaksespada10 Januari2019. Kartikasari, N. (2014). Pengaruh Komunikasi Pemasaran Terpadu terhadap Ekuitas Merek. Interaksi: Jurnal Ilmu Komunikasi, 3(2), 162-167. https://doi. org/10.14710/interaksi.3.2.162-167

Kotler, Philip dan Amstrong. 2008. PrinsipPrinsip Pemasaran, Jilid I, Edisi Kedelapan. Jakarta: Erlangga. Kriyantono, R. (2019). Aplikasi Teori Osgood untuk Evaluasi Pemaknaan Internal Strategi Komunikasi Pemasaran Co-branding. Jurnal Ilmu Komunikasi, 17(2), 193-204. Diakses dari http://jurnal.upnyk.ac.id/ index.php/komunikasi/article/view/2855

Lestari, P., \& Dewi, M. A. (2010). Model Komunikasi dalam Sosialisasi Pengarusutamaan Gender dan Anggaran ResponsifGender di Provinsi Daerah Istimewa Yogyakarta. Jurnal Ilmu Komunikasi, 8(2), 191203.Diakses dari http://jurnal.upnyk.ac.id/ index.php/komunikasi/article/view/80 Littlejohn, Stephen W \& Karen A. Foss. (2017). Theories Of Human Communication, Eleventh Edition. USA: Waveland Press.
Maharani, B. K., Lestari, P., \& Suparno, B. A. (2009). Analisis Strategi Komunikasi Pemasaranpt Roda Pembangunan Jaya dalam Memasarkanperumahan Taman Palagan Asri Di Yogyakarta. Jurnal Ilmu Komunikasi, 7(1), 38-48. Diakses dari http://jurnal.upnyk. ac.id/index.php/komunikasi/article/view/3 Resmawa, I. N. (2017). Strategi Komunikasi Pemasaran Dalam Memasarkan Produk Cemilan Kerupuk Singkong Samiler "Samijali" di Ukm Eks Lokalisasi Dolly. IKRA-ITH HUMANIORA: Jurnal Sosial dan Humaniora, 1(2), 68-75. Diakses dari https://journals.upi-yai.ac.id/index. php/ikraith-humaniora/article/view/153 Sabon, V. L., Perdana, M. T. P., Koropit. P, C, S., \& Pierre, W. C. D. (2018). Strategi Peningkatan Kinerja Sektor Parawisata Indonesia Pada Asean Economic Community. Esensi: Jurnal Bisnis dan Manajemen, 8 (2), 163 176. https://doi.org/10.15408/ess.v8i2.5928 Sugiyono.(2013). MetodePenelitian; Kuantitatif, Kualitatif dan $R \& D$. Bandung: Alfabeta. Suparwoko, \& Dewi, P. (2015). Model Rancangan Rumah Susun Di Kampung Wisata Jetisharjo Yogyakarta dengan Pendekatan Green Landscape dan Green Façade. Jurnal Sains dan Teknologi Lingkungan, 7(2), 108-122. https://doi.org/10.20885/jstl.vol7.iss2.art5 